\title{
Purification and structural elucidation of three bioactive compounds isolated from Streptomyces coelicoflavus BC 01 and their biological activity
}

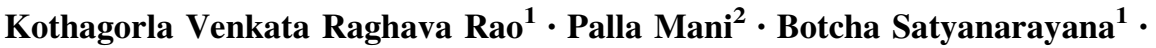 \\ Tamanam Raghava Rao ${ }^{1}$
}

Received: 30 October 2016/Accepted: 1 December 2016/Published online: 11 April 2017

(c) The Author(s) 2017. This article is an open access publication

\begin{abstract}
The strain Streptomyces coelicoflavus BC 01 was isolated from mangrove soil and used as inoculum for submerged fermentation. The fermented broth was extracted with ethyl acetate, the crude extract was subjected to silica gel column chromatography and the homogeneity of the isolated fractions was determined by TLC and then subjected to RP-HPLC for their purity. The purification steps led to the isolation of three pure bioactive compounds named as BC 01_C1, BC 01_C2 and BC 01_C3. The chemical structure of these three compounds was established on the basis of their spectroscopic studies like UV, IR, ${ }^{1} \mathrm{H}$ and ${ }^{13} \mathrm{C}$ NMR and GC-MS data by comparison with reference data from literature. The structure of the compound BC 01_C1 was established as 5-amino-2-(6(2-hydroxyethyl)-3-oxononyl) cyclohex-2-enone. The compound BC 01_C2 was established as8-(aminomethyl)7-hydroxy-1-(1-hydroxy-4-(hydroxylmethoxy)-2,3-dimethylbutyl)-2-methyl dodecahydro phenanthren-9(1H)-one and the compound BC 01_C3 was established as1-((E)-2ethylhex-1-en-1-yl)2-((E)-2-ethylidenehexyl)cyclohexane1,2-dicarboxylate. The MIC values of the three isolated compounds (BC 01_C1, BC 01_C2 and BC 01_C3) were found between $12.5-75 \mu \mathrm{g} / \mathrm{ml}$ for bacteria and $50-125 \mu \mathrm{g} /$ $\mathrm{ml}$ for fungi used in this study. These compounds also possess in vitro antioxidant and anti-inflammatory activities.
\end{abstract}

Kothagorla Venkata Raghava Rao

kv.raghavarao@yahoo.co.in

1 Department of Biochemistry, Andhra University, Visakhapatnam, Andhra Pradesh 530 003, India

2 Department of Organic Chemistry, Andhra University, Visakhapatnam 530 003, India
Keywords Fermentation - Streptomyces coelicoflavus BC $01 \cdot$ Chromatography $\cdot$ Antioxidant $\cdot$ Anti-inflammatory

\section{Introduction}

The development of resistance to multiple drugs is a major problem in the treatment of infections by pathogenic microorganisms. This antimicrobial resistance is presently an urgent focus of research and novel bioactive compounds are necessary to combat these pathogens. Microbial natural products are the most important source of new medicines. Among the potential sources of natural products bacteria are very important (Newman and Cragg 2007). However, the ability to produce anti-infective agents is limited to 5 of the 53 known phyla of bacteria. The most productive are members of the class actinobacteria; approximately 7000 compounds reported in the dictionary of natural products are of actinobacterial origin. Therefore, pharmaceutical industries are mainly focused on production of actinomycetes because of their ability to produce secondary metabolites (Berdy 2005). The secondary metabolites are organic compounds that are not directly involved in the normal growth, development or reproduction of the producing organism (Martín et al. 2005). The secondary metabolites are secreted during the generation of aerial hyphae from the vegetative mycelium (Maguelez et al. 2000). The medical uses of these secondary metabolites are not just limited to antibiotics but also include antibacterial, antifungal, antiviral, anticancer, antiparasitics, immunosuppressant agents, insecticides, herbicides, vitamins and enzymes, etc. (Newman and Cragg 2007). Other secondary metabolites produced by actinomyctes such as aliphatic alcohols, lactones, biogenic sulphides, ketones, esters, thioesters, lactones, furanones and isoprenoids are 
important to the chemical and pharmaceutical industries (Zaitlin and Watson 2006).

The genus Streptomyces is an economically important group of organisms among actinomycetes and they are the key source for wide range of biologically active compounds (Berdy 2005). About three-quarters of all the known commercially and medicinally useful antibiotics and several agriculturally important compounds were obtained from the Streptomyces sp. (Cundlife 1989). Furthermore, approximately $60 \%$ of the antibiotics discovered in the year 1990 and most of the antibiotics used in agriculture are from the genus Streptomyces. They have the ability to synthesize many biological activity compounds; hence they are extensively used as an important research subject from the academicians and as well as industrialists (Tanaka and Mura 1993). The present study describes the extraction, purification and the structural elucidation of three bioactive compounds from a liquid culture broth of the strain Streptomyces coelicoflavus BC 01 which was isolated from mangrove soil of Visakhapatnam, Andhra Pradesh, India. The biological activities of these three compounds are also addressed in the study.

\section{Materials and methods}

\section{Isolation and maintenance}

The sediment samples were collected from mangrove environment $\left(16^{\circ}-30^{\prime}\right.$ to $17^{\circ}-00^{\prime} \mathrm{N}$ latitudes and $82^{\circ}-14^{\prime}$ to $82^{\circ}-23^{\prime}$ E longitudes) near Dockyard, Visakhapatnam. The $\mathrm{pH}$ of the soil is around 7.6-8.0 and the salinity of the soil is of sandy texture. The soil sample was collected from 5 to $10 \mathrm{~cm}$ depth during the months of April-June 2010 by inserting sterile corer into the soil. Samples were transferred to a sterile polythene bag and stored under aseptic conditions until further use. The strain $S$. coelicoflavus BC 01 was previously isolated from the soil sample collected at mangrove area in Visakhapatnam, Andhra Pradesh, India (Rao and Rao 2013). This strain was isolated by soil dilution plate technique using yeast extract malt extract glucose agar (ISP 2) media with the addition of $2.5 \mathrm{mg} / \mathrm{ml}$ of rifampicin and $75 \mathrm{mg} / \mathrm{ml}$ of fluconazole to inhibit unwanted bacterial and fungal contaminations, respectively. The strain was sub-cultured on starch casein agar medium incubated at $28^{\circ} \mathrm{C}$ for 5-7 days to achieve good sporulation and was preserved at $4{ }^{\circ} \mathrm{C}$ in refrigerator for further use.

\section{Inoculum preparation of Streptomyces coelicoflavus BC 01}

The isolate $S$. coelicoflavus BC 01 was used in the present study. $5 \mathrm{ml}$ of sterile $0.9 \% \mathrm{NaCl}$ solution was added to 7-day-old well-sporulated slant of the culture. The spores were scraped from the slant into sterile saline solution and the resulting spore suspension (10\%) was transferred aseptically into a 500-ml Erlenmeyer flask containing $200 \mathrm{ml}$ of inoculum medium. The inoculum medium comprises $(\mathrm{g} / \mathrm{L})$ glucose 10.0 , soya bean meal $10.0, \mathrm{NaCl}$ 10.0 and $\mathrm{CaCO}_{3} 5.0$ with $\mathrm{pH}$ 7.0. The inoculated flasks were kept in an orbital shaker $(120 \mathrm{rpm})$ at $28^{\circ} \mathrm{C}$ for $48 \mathrm{~h}$. The contents of the flasks were centrifuged at $3000 \mathrm{rpm}$ for $10 \mathrm{~min}$ and the supernatant discarded. The cell pellet was washed thoroughly and suspended in $0.9 \% \mathrm{NaCl}$ solution. This cell suspension was used as inoculum.

\section{Submerged fermentation process for antibiotic production}

The submerged fermentation (6 L) was conducted by shake flask method in $500 \mathrm{ml}$ Erlenmeyer flasks. A 10\% (v/v) of $48 \mathrm{~h}$ aged inoculum was transferred to $200 \mathrm{ml}$ of production medium having composition glucose $12.0 \mathrm{~g} / \mathrm{L}$; Soya bean meal $10.0 \mathrm{~g} / \mathrm{L} ; \mathrm{K}_{2} \mathrm{HPO}_{4} 2.5 \mathrm{~g} / \mathrm{L}, \mathrm{NaCl} 10.0 \mathrm{~g} / \mathrm{L}$; trace salt solution $1.0 \mathrm{ml}\left\{\left(\mathrm{CuSO}_{4} \cdot 5 \mathrm{H}_{2} \mathrm{O}(0.64 \mathrm{~g} / \mathrm{L}) ; \mathrm{FeSO}_{4}\right.\right.$ $7 \mathrm{H}_{2} \mathrm{O}(0.11 \mathrm{~g} / \mathrm{L}) ; \mathrm{MnCl}_{2} \cdot 4 \mathrm{H}_{2} \mathrm{O}(0.79 \mathrm{~g} / \mathrm{L}) ; \mathrm{ZnSO}_{4} \cdot 7 \mathrm{H}_{2} \mathrm{O}$ $(0.15 \mathrm{~g} / \mathrm{L})\}$ with $\mathrm{pH}$ of the medium 7.2 in $500 \mathrm{ml}$ Erlenmeyer flasks (30 flasks were used, each flask containing $200 \mathrm{ml}$ of the production medium). All the flasks were incubated on a rotary shaker $(160 \mathrm{rpm})$ at $30{ }^{\circ} \mathrm{C}$ for $96 \mathrm{~h}$ and then harvested. After harvesting, the dark pink colour culture broth $(6 \mathrm{~L})$ was filtered using Whatmann No. 1 filter paper to separate mycelium from the liquid phase. The mycelial cake was centrifuged at $4000 \mathrm{rpm}$ for $10 \mathrm{~min}$ and a clear culture filtrate separated.

\section{Extraction of crude antibiotic from fermented broth}

The solvent extraction was used for the first step in the whole separation process. The clear culture filtrate $(1 \mathrm{~L})$ was extracted twice with ethyl acetate of 1:1 (v/v) and shaken vigorously for $1 \mathrm{~h}$ for complete extraction. The ethyl acetate phase that contains bioactive compound was separated from the aqueous phase. It was evaporated to dryness under reduced vacuum $80^{\circ}-90^{\circ} \mathrm{C}$. The obtained crude ethyl acetate extract was subjected to column chromatography.

\section{Purification of compounds from crude ethyl acetate extract by column chromatography}

Silica gel of 100-200 $\mu \mathrm{m}$ particle size was selected for column chromatography. The silica gel was suspended in chloroform for packing the column. The column consisted of a 40-cm-long corning glass tube having an internal diameter of $2.5 \mathrm{~cm}$ with a glass stopper at the 
bottom. The lower end of the tube contained stinted disc and the washed silica gel suspension was introduced gradually to obtain an air-bubble free continuous column. The final size of the column was $25 \times 2.5 \mathrm{~cm}$. The column was equilibrated with chloroform. The sample not exceeding $5 \mathrm{ml}$ was passed through the column keeping the flow rate at $0.2 \mathrm{ml} / \mathrm{min}$. with gradient solvent system consisting of chloroform: methanol (9:1, 7:3, 1:1). Finally the column was washed with methanol. Fractions of $5 \mathrm{ml}$ with each solvent system were collected and all the individual fractions were analysed by TLC for homogeneity.

\section{Determination of homogeneity of the fractions}

The homogeneity of the isolated fractions was determined by Reverse Phase partition TLC using polar phase solvent system chloroform: methanol and non-polar phase solvent system $5 \%(\mathrm{v} / \mathrm{v}) \mathrm{n}$-hexane in petroleum ether. TLC was carried out on silica gel $60 \mathrm{~F}_{254}$ plates (Merck, $0.25 \mathrm{~mm}$ ) impregnated with non-polar phase by immersing the activated plate into a solution of the nonpolar phase and allowing the solvent to evaporate. Approximately $10 \mu \mathrm{l}$ of the each fraction was applied with a capillary tube. The chromatograms were run and the spots on the TLC plates were visualized by keeping them in a closed chamber containing iodine vapours. Fractions with similar $R_{f}$ values were pooled together and evaporated to dryness under reduced vacuum to check their purity.

\section{Checking the purity of compounds by reverse-phase high-performance liquid chromatogram (RP-HPLC)}

HPLC is a very popular method and is widely used to separate and quantify compounds for the identification and isolation of bioactive natural products. The purity of the antibiotic compounds was analysed by analytical HPLC supported with Waters Spherisorb $5 \mu \mathrm{m}$ ODS2 $4.6 \mathrm{X}$ $250 \mathrm{~mm}$ analytical cartridge (C-18 column) on a Waters 515 pump; isocratic Reverse phase system with a 2998 photodiode array detector at $210 \mathrm{~nm}$ and the range given was $190-600 \mathrm{~nm}$. The flow rate was $1.0 \mathrm{ml} / \mathrm{min}$, and additional UV detector was measured at $254 \mathrm{~nm}$ using Empower 2 software. Methanol was used as mobile phase. The purified compounds were mixed with HPLC grade methanol and filtered by using $0.22 \mu$ Millipore membrane filter before injecting into injection port. The samples were run for $15 \mathrm{~min}$ and the retention time was noted; based on the percentage of area of the peak the purity of the compound was known.

\section{Structural elucidation of the antibiotic compounds}

\section{Solubility}

The solubility pattern of the compound was determined in various polar and non-polar solvents.

\section{Melting point}

The melting points were recorded on Kumar capillary melting point apparatus and are uncorrected.

\section{$U V$-absorption spectrum}

Ultraviolet (UV) spectrums were recorded on Shimadzu UV-1800 spectrophotometer. The compounds obtained from $S$. coelicoflavus BC 01 were dissolved in methanol at a concentration of $1 \mathrm{mg} / \mathrm{ml}$ and the spectrums were recorded at 200-500 $\mathrm{nm}$ range using UV-Probe software.

\section{FT-IR spectrum}

The infrared spectra were recorded on Shimadzu IR-470 model. The spectra were scanned in the range of $750-3500 \mathrm{~cm}^{-1}$. The spectra were obtained using potassium bromide pellet technique. The spectra were plotted as intensity versus wave number. The FT-IR spectra were analysed for the presence of functional groups in pure compounds.

\section{Mass spectrum}

The purified compounds were analysed on Agilent GC-MS system (GC: 5890 series II; MSD 5972). The fused-silica HP-5 capillary column $(30 \mathrm{~m} \times 0.25 \mathrm{~mm}$, ID, film thickness of $0.25 \mathrm{~mm}$ ) was directly coupled to the MS. The carrier gas was helium with a flow rate of $1.2 \mathrm{ml} \mathrm{min}^{-1}$. Oven temperature was programmed $\left(50^{\circ} \mathrm{C}\right.$ for $1 \mathrm{~min}$, then 50-280 ${ }^{\circ} \mathrm{C}$ at a rate of $5{ }^{\circ} \mathrm{C} / \mathrm{min}$ ) and subsequently held isothermally for $20 \mathrm{~min}$. The temperature of injector port was maintained at $250{ }^{\circ} \mathrm{C}$ and that of detector at $280{ }^{\circ} \mathrm{C}$. The peaks of the obtained components in gas chromatography were subjected to mass-spectral analysis.

\section{${ }^{1} H$ and ${ }^{13} C N M R$}

The nuclear magnetic resonance (NMR) spectra of purified compounds were recorded on $400 \mathrm{MHz}$ Fourier transform nuclear magnetic resonance (Bruker Model: Avance-II) spectrophotometer. The chemical shifts were expressed in $\delta$ (ppm) using $\mathrm{CDCl}_{3}$ as solvent and trimethylsilane (TMS) as internal reference. 


\section{Biological activities of the purified compounds}

\section{Minimum inhibitory concentration (MIC)}

Different concentrations of the purified compounds (12.5, $25,50,75,100,125,150,175,200$ and $250 \mu \mathrm{g} / \mathrm{ml})$ were tested for their minimum inhibitory concentration (MIC) against bacteria and fungi by using agar well diffusion method (Wiegand et al. 2008). The results were expressed as the minimum concentration of the compound for total inhibition against bacterial or fungal growth. The test organisms procured from IMTECH, Chandigarh and used for the determination of minimum inhibitory concentration (MIC)were S. aureus (MTCC 3160), B. subtilis (MTCC 441), B. cereus (MTCC 430), P. aeruginosa (MTCC 424), E. coli (MTCC 443), P. vulgaris (MTCC 426), C. albicans (MTCC 227), A. niger (MTCC 961), A. flavus (MTCC 3396) and S. cerevisiae (MTCC 170).

\section{DPPH $(1,1$, diphenyl-2-picryl hydrazyl) scavenging} activity

DPPH was assayed by the method of Parasuraman et al. (2010) with slight modifications. Different concentrations $(5,10,15$ and $20 \mu \mathrm{g} / \mathrm{ml})$ of above compounds and crude were dissolved in methanol and taken in test tubes separately. Ascorbic acid was used as a reference standard. DPPH $0.004 \%$ was freshly prepared in methanol. DPPH ( $2 \mathrm{ml})$ was added to each tube containing different concentrations of compounds $(1 \mathrm{ml})$ and of standard solution $(1 \mathrm{ml})$. It was shaken vigorously. They were then allowed to stand for $30 \mathrm{~min}$ at room temperature in dark place. The control was prepared without any compound. Methanol was used for base line corrections and absorbance (OD) of sample was measured at $517 \mathrm{~nm}$. The below formula was used to interpret the value of the sample.

$$
\begin{aligned}
& \% \text { Radical scavenging activity } \\
& =[(\text { Control O.D }- \text { sample O.D }) / \text { Control OD }] \times 100
\end{aligned}
$$

\section{Ferric reducing antioxidant power assay (FRAP)}

FRAP assay was carried out according to the method of Benzie and Strain (1996). FRAP assay uses antioxidants as reductants in a redox-linked colorimetric method, employing an easily reduced oxidant system present in stoichiometric excess. The FRAP reagent was prepared by mixing $300 \mathrm{mM}$ acetate buffer (pH 3.6), $10 \mathrm{mM}$ TPTZ and $20 \mathrm{mM} \mathrm{FeCl} 3 \cdot 6 \mathrm{H}_{2} \mathrm{O}$ in a ratio of $10: 1: 1$, at $37{ }^{\circ} \mathrm{C} .1 .5 \mathrm{ml}$ of the FRAP reagent was mixed with $0.5 \mathrm{ml}$ of the sample (compound) and the absorbance was measured at $593 \mathrm{~nm}$ after $15 \mathrm{~min}$. The results are expressed in $\mu$ moles $/ \mathrm{ml}$ of ascorbic acid equivalents.

\section{Determination of total antioxidant capacity}

The total antioxidant capacity was evaluated by the phosphomolybdenum method according to the procedure described by Prieto et al. (1999). The assay is based on the reduction of Mo (VI)-Mo (V) by the extract and subsequent formation of a green phosphate/Mo (V) complex at acid pH. $0.1 \mathrm{ml}$ of sample was taken in methanol, combined with $1.9 \mathrm{ml}$ of reagent solution (0.6 M sulphuric acid, $28 \mathrm{mM}$ sodium phosphate and $4 \mathrm{mM}$ ammonium molybdate). The tubes were capped and incubated at $95{ }^{\circ} \mathrm{C}$ for $90 \mathrm{~min}$. After the samples were cooled to room temperature, the absorbance was measured at $695 \mathrm{~nm}$ against a blank. Ascorbic acid equivalents were calculated using standard graph of ascorbic acid and values are expressed as ascorbic acid equivalents in $\mu \mathrm{g} / \mathrm{mL}$ of extract.

\section{In vitro anti-inflammatory activity}

The human red blood cell (HRBC) membrane stabilization method has been used to study the in vitro anti-inflammatory activity (Gandhidasan et al. 1991). Fresh blood sample was collected from healthy individual at the Andhra University dispensary and mixed with equal volume of sterilized Alsever solution (2\% dextrose, $0.8 \%$ sodium citrate, $0.05 \%$ citric acid and $0.42 \%$ sodium chloride in distilled water).The blood was centrifuged at $3000 \mathrm{rpm}$ and packed cells were washed with isosaline $(0.85 \%, \mathrm{pH} 7.2)$ and a suspension was made with isosaline $(10 \% \mathrm{v} / \mathrm{v})$.

\section{Membrane stabilization assay}

The assay mixture contained $1 \mathrm{ml}$ of phosphate buffer (0.15 M, pH 7.4), $2 \mathrm{ml}$ of hyposaline (0.36\%), $0.5 \mathrm{ml}$ of HRBC suspension and $1 \mathrm{ml}$ of various concentrations of the test compound. Diclofenac sodium was used as reference drug. In the control solution, instead of hyposaline, $2 \mathrm{ml}$ of distilled water was added. The mixtures were incubated at $37^{\circ} \mathrm{C}$ for $30 \mathrm{~min}$ and centrifuged. The absorbance of the supernatant solution was read at $560 \mathrm{~nm}$. The percentage of haemolysis was calculated by assuming the haemolysis produced in the presence of distilled water as $100 \%$. The percentage of HRBC membrane stabilization was calculated using the following formula:

Percentage of membrane stabilization

$$
=\frac{100-\text { OD of drug treated sample }}{\text { OD of control }} \times 100
$$

\section{Statistical analysis}

The structure of the compounds was drawn using ChemBioOffice Version 12. All investigations were conducted in triplicate and the attained data were subjected to 
one-way ANOVA using SPSS version 16 and the significance level was 0.05 . The obtained data were expressed as mean \pm standard error.

\section{Results and discussion}

In microbial community mangrove actinomycetes become a hot spot for isolation of natural products. Currently, 122 various secondary metabolites were isolated from mangrove actinomycetes; of these, 73 compounds were novel and remaining compounds were predicted previously (Xu et al. 2014). It has long been known that some of the Streptomyces strains of the similar species might produce different antibiotics, whereas certain other strains belonging to different species produced the identical antibiotics (Lechevalier 1975). Therefore, the production of antibiotics by Streptomyces could not be species-specific, but slightly strain-specific. Antibiotics of Streptomyces origin evidence a wide variety of chemical structures, including aminoglycosides, anthracyclines, glycopeptides, $\beta$-lactams, macrolides, nucleosides, peptides, polyenes, polyketides, actinomycins and tetracyclines (Baltz 1998). In the present study the isolate Streptomyces coelicoflavus BC 01 was extracted using ethyl acetate. The ethyl acetate extract was then evaporated to dryness under reduced vacuum at $80-90{ }^{\circ} \mathrm{C}$ in a rotary evaporator. The crude extract appeared as pink-coloured solid material and about $5 \mathrm{~g}$ was obtained from the culture filtrate $(61)$.

\section{Purification of compounds from crude ethyl acetate extract by column chromatography}

The ethyl acetate extract was purified using silica gel column chromatography. About $5 \mathrm{~g}$ of the crude ethyl acetate extract was chromatographed on silica gel column and eluted with gradient solvent system consisting of $100 \%$ chloroform: methanol in the ratio of 9:1, 7:3, 1:9 and followed by $100 \%$ methanol. A total of 120 fractions of $5 \mathrm{ml}$ each were collected. The purity of all the fractions was analysed by TLC. The fractions with similar Rf values were pooled together, which ultimately resulted in three major fractions. Each of these fractions was evaporated to dryness under reduced vacuum. The obtained fractions were named as fraction I (360 mg), fraction II (526 mg) and fraction III (230 mg). Fraction I was obtained with eluent by $100 \%$ chloroform and fraction II was obtained with eluent 9:10 $\mathrm{CHCl}_{3}: \mathrm{CH}_{3} \mathrm{OH}$, whereas fraction III by $100 \%$ methanol. These three fractions were designated as BC 01_C1, BC 01_C2 and BC 01_C3. All these fractions were characterized by spectral analysis and also tested for their minimum inhibitory concentration against the test organisms, in vitro antioxidant and anti-inflammatory activity.

\section{Structural elucidation of purified compounds}

Compound BC 01_C1

The compound BC 01_C1 was isolated as a pink-colour amorphous powder soluble in methanol, chloroform, ethyl acetate, diethyl ether, ethanol, acetone, benzene, DMSO and insoluble in hexane. The melting point of the compounds was found to be $275^{\circ} \mathrm{C}$. The purity of the compound BC 01_C1was evidenced by HPLC and found to be $99.5 \%$. The UV spectrum of the purified compound $\mathrm{BC}$ 01_C1 was dissolved in methanol and the spectrum displayed. Absorption maxima $\left(\lambda_{\max }\right)$ at $207 \mathrm{~nm}$ indicate the presence of cyclohexenone ring and $\lambda_{\max }$ at $273 \mathrm{~nm}$ indicates the presence of keto group, respectively. ${ }^{1} \mathrm{H}$ NMR $\left(\mathrm{CDCl}_{3}\right.$ : TMS $\left.400 \mathrm{MHz}\right)$ the spectrum of the compound showed $\delta 0.9\left(\mathrm{CH}_{3}\right.$ proton $), \delta$ 1.25-1.28 $\left(\mathrm{CH}_{2}\right.$ proton adjacent to $\mathrm{CH}_{3}$ group), $\delta 1.48-1.49$ ( $\mathrm{CH}$ proton), $\delta$ 2.04-2.36 ( $\mathrm{CH}_{2}$ proton), $\delta 3.64$ (O-H proton), $\delta$ 5.34-5.35 (N-H proton), $\delta 6.9\left(\mathrm{H}-\mathrm{C}=\mathrm{C}\right.$ proton). ${ }^{13} \mathrm{CNMR}\left(\mathrm{CDCl}_{3}\right.$ : TMS $400 \mathrm{MHz}) \delta 14.3\left(\mathrm{CH}_{3}\right.$ carbons $), \delta 22.8\left(\mathrm{CH}_{2}\right.$ carbon adjacent to $\mathrm{CH}_{3}$ group), $\delta$ 30.37-34.14( $\mathrm{CH}_{2}$ carbon), $\delta$ $36.8-39.2\left(\mathrm{CH}_{2}\right.$ carbon adjacent to $\mathrm{C}=\mathrm{O}$ group $), \delta 65.2$ $\left(\mathrm{CH}_{2}\right.$ carbon adjacent to $\mathrm{OH}$ group), $\delta$ 130.1-130.2 (olefimic carbon adjacent to $\mathrm{C}=\mathrm{O}$ ) and $\delta 210$ (carbonyl $(\mathrm{C}=\mathrm{O}$ ) carbon). IR spectrum of the compound showed the presence of primary $\mathrm{O}-\mathrm{H}$ stretching at $1103 \mathrm{~cm}^{-1}, 1165 \mathrm{~cm}^{-1}$ indicates carbon adjacent to keto group; $1381,1465 \mathrm{~cm}^{-1}$ indicates $\mathrm{CH}$ stretching adjacent to $\mathrm{C}=\mathrm{O} ; 1735 \mathrm{~cm}^{-1}$ indicates $\mathrm{C}=\mathrm{O}$ stretching in ketone; 2252, 2684, 2731, $2854 \mathrm{~cm}^{-1}$ represents $\mathrm{C}=\mathrm{C}$ stretching; $2924 \mathrm{~cm}^{-1}$ indicates $\mathrm{CH}$ stretching in methylene group and $3150 \mathrm{~cm}^{-1}$ indicates $\mathrm{N}-\mathrm{H}$ stretching of amino group. EI MS M/Z \% the molecular formula of the compound BC 01_C1 was deduced as $\mathrm{C}_{17} \mathrm{H}_{29} \mathrm{NO}_{3}$ based on the results of elemental analysis (Anal Cal. for $\mathrm{C}_{23} \mathrm{H}_{41} \mathrm{NO}_{5}$ : C 69.12\%, H 9.89\%, N $4.74 \%, 0$ 16.25\%; Found C 70.02\%, H 10.09\%, N 5.14\%, 0 $14.75 \%)$ and in accordance with the number of carbon atoms observed on ${ }^{13} \mathrm{C}$ NMR. The electron impact (EI) mass spectrum confirmed that the molecular weight of the antibiotic compound was 295.31. Based on the above spectral data by comparison with literature, the structure of the compound BC 01_C1 was established as 5-amino-2-(6(2-hydroxyethyl)-3-oxononyl) cyclohex-2-enone and depicted in Fig. 1.

\section{The compound BC 01_C2}

The compound was isolated as a brown colour amorphous powder soluble in methanol, chloroform, ethyl acetate, benzene, acetone, ethanol, diethyl ether, DMSO and insoluble in hexane. The melting point of the compounds was found to be $401{ }^{\circ} \mathrm{C}$. The purity of the newly isolated 

compound BC 01_C1
Fig. 1 Structure of the<smiles>CCCC(CCO)CCC(=O)CCC1=CCC(N)CC1=O</smiles>

compound was evidenced by HPLC and found to be $98.89 \%$. The UV spectrum of the purified active compound was displayed absorption maxima at $204 \mathrm{~nm}$ characteristic of phenanthrenone $\lambda_{\max }$ at $360 \mathrm{~nm}$ and $406 \mathrm{~nm}$ indicates the presence of hydroxyl and amino group respectively. ${ }^{1} \mathrm{H}$ NMR $\left(\mathrm{CDCl}_{3}\right.$ : TMS $\left.400 \mathrm{MHz}\right) \delta 0.977\left(\mathrm{CH}_{3}\right.$ proton); $\delta$ $1.0-1.832$ ( $\mathrm{CH}$ protons in cyclohexane ring); $\delta 2.04-2.31$ ( $\mathrm{CH}$ protons attached to $-\mathrm{C}=\mathrm{O}$ group); $\delta 2.29$ ( $\mathrm{CH}$ protons in cyclohexane attached to $-\mathrm{CH}_{2} \mathrm{NH}_{2}$ group); $\delta 3.49\left(\mathrm{CH}_{2}\right.$ protons attached to $-\mathrm{CH}_{2}-\mathrm{O}-\mathrm{CH}_{2}$ linkage); $\delta 3.574(\mathrm{OH}$ protons attached to cyclohexane); $\delta 3.645(\mathrm{OH}$ protons attached to $-\mathrm{CH}_{2}-\mathrm{O}-\mathrm{CH}_{2}$ linkage); $\delta 5.011\left(\mathrm{NH}_{2}\right.$ protons); $\delta 5.345\left(\mathrm{CH}_{2}\right.$ protons). ${ }^{13} \mathrm{C} \mathrm{NMR}\left(\mathrm{CDCl}_{3}\right.$ : TMS400 $\left.\mathrm{MHz}\right)$ $\delta 14.31\left(\mathrm{CH}_{3}\right.$ carbons); $\delta 22.88-32.116$ (cyclohexane carbons attached to $\mathrm{CH}_{3}$ group); $\delta 76.88\left(\mathrm{CH}_{2}\right.$ carbon attached to $\mathrm{CH}_{2}-\mathrm{O}-\mathrm{CH}_{2}$ group); $\delta$ 77.2-77.5 (cyclohexane carbons); $\delta 100.31\left(\mathrm{CH}_{2}\right.$ carbon attached to $\mathrm{OH}$ group $) ; \delta$ 211.5 ( $\mathrm{C}=\mathrm{O}$ carbon).IR spectrum of the compound showed $1111.0,1172.72,1373.32,1465.90,1820 \mathrm{~cm}^{-1}$ indicates (COOme); 3100 and $3150 \mathrm{~cm}^{-1}$ indicates $(\mathrm{N}-\mathrm{H}$ stretching). EI MS M/Z \%: the molecular formula of the antibiotic compound BC 01_C2 was deduced as $\mathrm{C}_{23} \mathrm{H}_{41} \mathrm{NO}_{5}$ based on the results of elemental analysis (Anal Cal. for $\mathrm{C}_{23} \mathrm{H}_{41} \mathrm{NO}_{5}$ : C $67.12 \%, \mathrm{H} 10.04 \%, \mathrm{~N} \mathrm{3.40 \% ,0} 19.44 \%$; Found C $68.14 \%, \mathrm{H} 11.24 \%, \mathrm{~N} 2.90 \%, 017.72 \%$ ) and in accordance with the number of carbon atoms observed on ${ }^{13} \mathrm{C}$ NMR. The electron impact (EI) mass spectrum confirmed that the molecular weight of the compound was 411.2. Based on the above spectral data by comparison with literature, the structure of the compound BC 01_C2 was established as 8-(aminomethyl)-7-hydroxy-1-(1-hydroxy-4-(hydroxylmethoxy)-2,3-dimethylbutyl)-2-methyldodecahydro phenanthren-9(1H)-one and shown in Fig. 2.

\section{The compound BC 01_C3}

The compound was isolated as a pale yellow colour amorphous powder soluble in methanol, chloroform, ethyl acetate, diethyl ether, ethanol, acetone, benzene, DMSO and insoluble in hexane. The melting point of the compounds was found to be $136.3{ }^{\circ} \mathrm{C}$. The purity of the newly isolated compound was evidenced by HPLC and found to

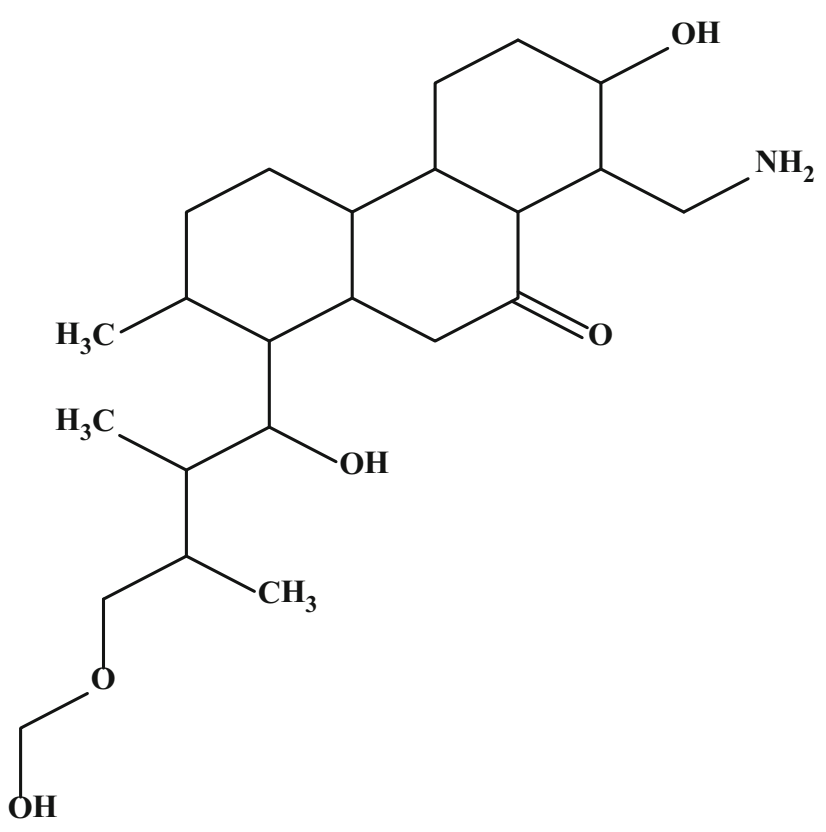

Fig. 2 Structure of the compound BC 01_C2

be $99.34 \%$. The UV spectrum of the purified compound displayed absorption maxima at $203 \mathrm{~nm}$ indicates the presence of carboxylate group, $207 \mathrm{~nm}$ indicates the presence of cyclohexane-1,2-dicarboxylate and $360 \mathrm{~nm}$ indicates the presence of ethylidenehexyl group. ${ }^{1} \mathrm{H}$ NMR $\left(\mathrm{CDCl}_{3}\right.$ : TMS $\left.400 \mathrm{MHz}\right) \delta 0.94\left(\mathrm{CH}_{3}\right.$ proton $) ; \delta 1.29-1.48$ $\left(\mathrm{CH}_{2}\right.$ protons attached to $\mathrm{CH}_{3}$ group); $\delta 1.51$ ( $\mathrm{CH}$ protons in cyclohexane); $\delta 2.05\left(\mathrm{CH}_{3}\right.$ protons attached to $-\mathrm{C}=\mathrm{C}-\mathrm{H}$ group); $\delta 2.804(\mathrm{CH}$ protons in cyclohexane); $\delta 5.37$ $(-\mathrm{C}=\mathrm{C}-\mathrm{H}$ proton $) ; \delta 6.8(-\mathrm{C}=\mathrm{C}-\mathrm{H}$ proton attached to ester linkage). ${ }^{13} \mathrm{C}$ NMR $\left(\mathrm{CDCl}_{3}\right.$ : TMS $\left.400 \mathrm{MHz}\right) \delta 11.60\left(\mathrm{CH}_{3}\right.$ attached to ethylene carbons); $\delta 22.8-32.11\left(\mathrm{CH}_{2}\right.$ carbon adjacent to $\mathrm{CH}_{3}$ group); $\delta 69.04\left(\mathrm{CH}_{2}\right.$ carbon attached to ethylene group); $\delta 114.25$ (C=O carbons); $\delta 173.08\left(\mathrm{CH}_{2}\right.$ protons adjacent to $\mathrm{CH}_{2}-\mathrm{O}-\mathrm{CH}_{2}$ linkage); $\delta 173.50$ (-COO-carbon). IR spectrum of the compound showed $779.24,910.40 \mathrm{~cm}^{-1}$ (-C-O stretching), 1018.41, 1103.28, $1165.00, \quad 1373.32, \quad 1465.90, \quad 1597.06 \mathrm{~cm}^{-1} \quad(\mathrm{C}-\mathrm{O}-\mathrm{C})$ group); $1735.93 \mathrm{~cm}^{-1}(\mathrm{C}=\mathrm{O})$ group stretching); 2283.72 , 2468.88, 2677.20, 2731.20, 2854.65, $2924.09 \mathrm{~cm}^{-1}$ (C-H stretching in esters). The molecular formula of the 
Fig. 3 Structure of the compound BC 01_C3

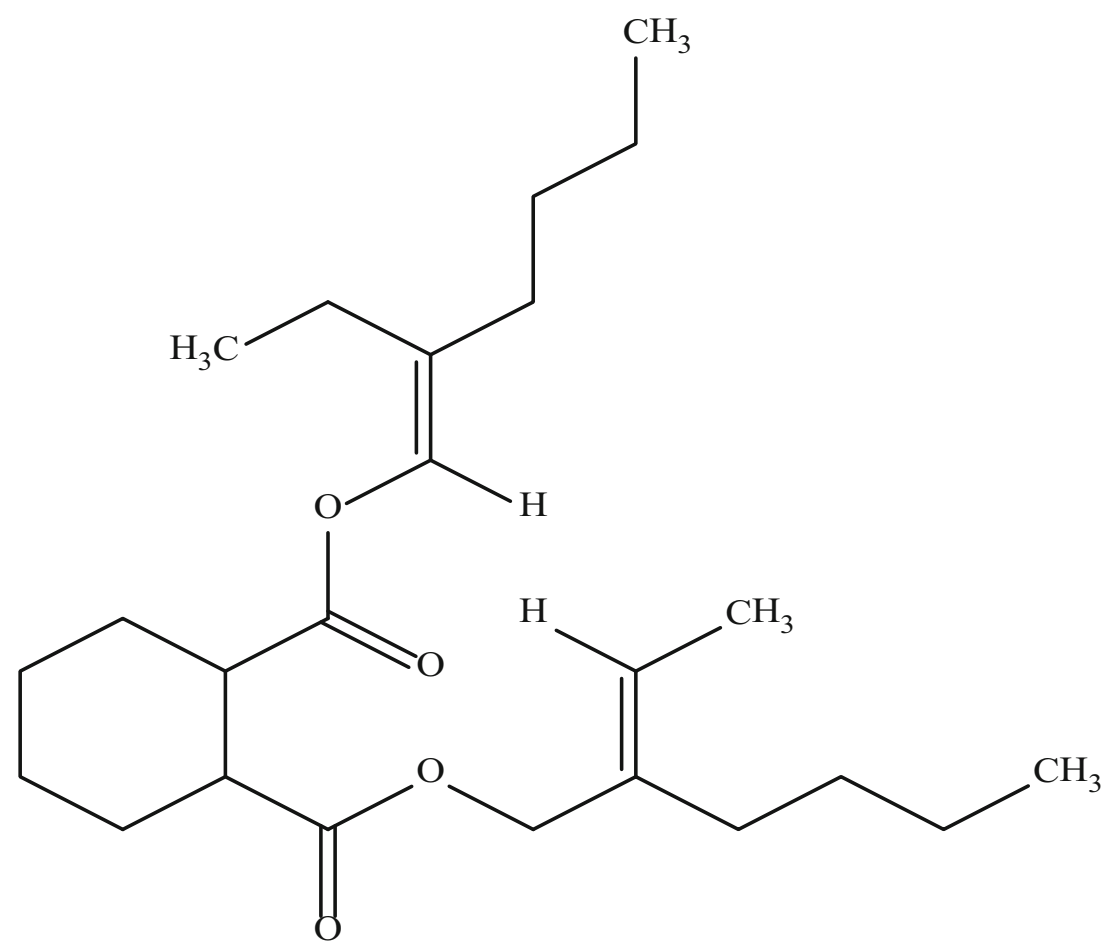

compound BC 01_C3 was deduced as $\mathrm{C}_{24} \mathrm{H}_{40} \mathrm{O}_{4}$ based on the results of elemental analysis (Anal Cal. for $\mathrm{C}_{24} \mathrm{H}_{40} \mathrm{O}_{4}$ : C $73.43 \%$, H 10.27\%, O 16.30; Found C 74.2\%, H $11.3 \%$, $014.5 \%$ ) and in accordance with the number of carbon atoms observed on ${ }^{13} \mathrm{C}$ NMR. The electron impact (EI) mass spectrum confirmed that the molecular weight of the antibiotic was 392.29. Based on the above spectral data by comparison with literature, the structure of the compound BC 01_C3 was established as 1-((E)-2-ethylhex-1-en-1yl)2-((E)-2-ethylidenehexyl) cyclohexane-1,2-dicarboxylate and shown in Fig. 3.

\section{Minimum inhibitory concentration (MIC)}

The isolate BC 01 (crude) exhibits the maximum antibacterial activity against $P$. vulgaris (zone of inhibition $38 \mathrm{~mm}$ ), whereas moderate activity was observed against E. coli $(35 \mathrm{~mm})$, B. subtilis $(35 \mathrm{~mm})$, S. aureus $(32 \mathrm{~mm})$, $P$. aeruginosa $(32 \mathrm{~mm})$ and $B$. cereus $(29 \mathrm{~mm})$. For antifungal studies, the isolate $\mathrm{BC} 01$ exhibits highest activity against $A$. niger $(28 \mathrm{~mm})$ and showed moderate activity against $C$. albicans $(19 \mathrm{~mm})$, A. flavus $(18 \mathrm{~mm})$ and $S$. cerevisiae (14 mm) (Raghava Rao et al. 2012).

The purified compounds showed broad spectrum of antimicrobial activity against both gram-positive, gramnegative bacteria and also fungi. The compounds obtained from S. coelicoflavus BC 01 were BC 01_C1, BC 01_C2 and BC 01_C3. The MIC of three compounds was shown in Table 1. The MIC of the compound BC 01_C1 was identified as $25 \mu \mathrm{g} / \mathrm{ml}$ for $S$. aureus, $P$. aeruginosa and $P$. vulgaris whereas $E$. coli and $B$. cereus were inhibited at $50 \mu \mathrm{g} / \mathrm{ml}$ and $B$. subtilis at $75 \mu \mathrm{g} / \mathrm{ml}$. In case of fungi the MIC was $100 \mu \mathrm{g} / \mathrm{ml}$ for $C$. albicans and $A$. niger, whereas $75 \mu \mathrm{g} / \mathrm{ml}$ for A. flavus and $50 \mu \mathrm{g} / \mathrm{ml}$ for $S$. cerevisiae. The MIC of the compound BC 01_C2 was observed at $12.5 \mu \mathrm{g} /$ $\mathrm{ml}$ for $S$. aureus and $P$. vulgaris. At $25 \mu \mathrm{g} / \mathrm{ml}$ concentration E. coli was inhibited, whereas B. Subtilis, B. cereus and $P$. aeruginosa were inhibited at $50 \mu \mathrm{g} / \mathrm{ml}$ concentration. For fungal studies the MIC value was observed at $75 \mu \mathrm{g} / \mathrm{ml}$ for A. niger, S. cerevisiae and $100 \mu \mathrm{g} / \mathrm{ml}$ for A. flavus and $125 \mu \mathrm{g} / \mathrm{ml}$ for $C$. albicans. The MIC of the compound BC 01_C3 was observed at $12.5 \mu \mathrm{g} / \mathrm{ml}$ for $E$. coli, and in case of $S$. aureus, B. cereus, $P$. aeruginosa and $P$. vulgaris at $25 \mu \mathrm{g} / \mathrm{ml}$, whereas for $B$. subtilis at $50 \mu \mathrm{g} / \mathrm{ml}$. In case of fungal studies the MIC value for $A$. niger and $S$. cerevisiae was $50 \mu \mathrm{g} / \mathrm{ml}$, whereas A. flavus was inhibited at $100 \mu \mathrm{g} /$ $\mathrm{ml}$ and $C$. albicans at $125 \mu \mathrm{g} /$. From the above observations it was evident that the compounds BC 01_C1, BC 01_C2 and BC 01_C3 were acting as potent antibiotics against both the bacteria and fungi.

The MIC of the three compounds BC 01_C1, BC 01_C2 and BC 01_C3 were tested against a wide variety of test organisms for which the MIC values ranged from 12.5 to $75 \mu \mathrm{g} / \mathrm{ml}$ for bacteria and 50 to $125 \mu \mathrm{g} / \mathrm{ml}$ for fungi. Similar investigations and results were obtained by Smaouia et al. (2011) where they reported three pure bioactive compounds named compound 1 (a diketopiperazine derivative), compound 2 (a phthalate derivative) and compound 3 (a cyclic tetrapeptide derivative) from Streptomyces sp. TN17 strain. These three active compounds 
Table 1 Minimum inhibitory concentrations of three compounds

\begin{tabular}{lccc}
\hline Name of the organism & \multicolumn{3}{l}{ Name of the compound } \\
\cline { 2 - 4 } & $\begin{array}{l}\text { BC 01_C1 } \\
(\mu \mathrm{g} / \mathrm{ml})\end{array}$ & $\begin{array}{l}\text { BC 01_C2 } \\
(\mu \mathrm{g} / \mathrm{ml})\end{array}$ & $\begin{array}{l}\text { BC 01_C3 } \\
(\mu \mathrm{g} / \mathrm{ml})\end{array}$ \\
\hline S. aureus (MTCC 3160) & 25 & 12.5 & 25 \\
B. subtilis (MTCC 441) & 75 & 50 & 50 \\
B. cereus (MTCC 430) & 50 & 50 & 25 \\
P. aeruginosa (MTCC 424) & 25 & 50 & 25 \\
E. coli (MTCC 443) & 50 & 25 & 12.5 \\
P. vulgaris (MTCC 426) & 25 & 12.5 & 25 \\
Fungi & & & \\
C. albicans (MTCC 227) & 100 & 125 & 125 \\
A. niger (MTCC 961) & 100 & 75 & 50 \\
A. flavus (MTCC 3396) & 75 & 100 & 100 \\
S. cerevisiae (MTCC 170) & 50 & 75 & 50 \\
\hline
\end{tabular}

possess potent antibacterial and antifungal activities. Likewise on purification of Streptomyces sp. Strain US80 led to isolation of three pure active compounds. The chemical structures of these three compounds are named as irumamycin (1a), X-14952B (1b) and17-hydroxy-venturicidin A (1c), which possess potent antimicrobial activities against gram-positive, gram-negative bacteria and fungi (Fguira et al. 2005). Similar studies were carried out by Mehdi et al. (2006) in which the strain Streptomyces sp. TN97 produces three compounds, which are diketopiperazine derivatives, isocoumarin derivative and the $\mathrm{N}$-acetyltyramine exhibits potent antimicrobial activities against gram-positive, gram-negative bacteria and fungi (Mehdi et al. 2006) and also compounds 5,7-dimethoxy-4-pmethoxylphenylcoumarin and 5,7-dimethoxy-4-phenylcoumarin isolated from $S$. aureofaciens CMUAc130 exhibited antifungal activities against tested fungi, and their MICs were found to be 120 and $150 \mu \mathrm{g} / \mathrm{ml}$ respectively and also two pure active compounds were isolated from Streptomyces sp. US24 possessed antibacterial activity against Gram-positive and Gram-negative bacteria (Mellouli et al. 2003).

\section{In vitro antioxidant activity}

In the present study, in vitro antioxidant activity of the three isolated compounds was evaluated by DPPH free radical scavenging, the ferric reducing power (FRAP) assay and total antioxidant capacity (TAC). Ascorbic acid was used as positive control. All the assays were carried out at concentrations of 5,10,15 and $20 \mu \mathrm{g} / \mathrm{ml}$ and the results were expressed as average of three independent experiments.

The DPPH free radical scavenging activity was expressed as \% of inhibition. Among the three compounds, BC 01_C3 $(63.44 \pm 0.67)$ exhibits the maximum inhibition of DPPH free radical scavenging activity followed by BC 01_C2 (61.92 \pm 6.95) and BC 01_C1 (52.39 \pm 1.68$)$, respectively, at $20 \mu \mathrm{g} / \mathrm{ml}$ of concentration. All the three compounds possess significant free radical scavenging activity when compared with reference standard ascorbic acid. ANOVA analysis showed that there was a significant variation of DPPH free radical scavenging activity between the three compounds BC 01_C1, BC 01_C2 and BC 01_C3. According to Duncan's grouping analysis there was a significant difference within each group at various concentrations. Among, these BC 01_C1 showed significant variation at concentrations of between 5,15 and $20 \mu \mathrm{g} / \mathrm{ml}$ and also a significant variation between 10 and $20 \mu \mathrm{g} / \mathrm{ml}$ concentrations. Compound BC 01_C2 exhibited significant variation between 5,15 and $20 \mu \mathrm{g} / \mathrm{ml}$, whereas BC 01_C3 showed significant variation for all the four concentrations. The results are tabulated in Table 2.

The ferric reducing antioxidant power was expressed as $\mu \mathrm{moles} / \mathrm{ml}$ of ascorbic acid equivalents. All the three compounds possess worthy activity when compared with the reference standard ascorbic acid; among the three

Table 2 DPPH activity of the three compounds

\begin{tabular}{|c|c|c|c|c|}
\hline \multicolumn{5}{|l|}{$\%$ Inhibition } \\
\hline \multirow[t]{2}{*}{ Concentration of the compounds $(\mu \mathrm{g} / \mathrm{ml})$} & \multicolumn{4}{|c|}{ Name of the compounds } \\
\hline & $\overline{\mathrm{BC} 01 \_\mathrm{C} 1 *}$ & BC 01_C2* & BC 01_C3* & Ascorbic acid* \\
\hline 5 & $34.81 \pm 5.56 \mathrm{a}$ & $36.82 \pm 2.12 \mathrm{a}$ & $36.38 \pm 2.12 \mathrm{a}$ & $47.03 \pm 15.9 \mathrm{a}$ \\
\hline 10 & $39.25 \pm 4.90 \mathrm{ab}$ & $43.69 \pm 1.42 \mathrm{a}$ & $47.01 \pm 0.87 b$ & $51.24 \pm 7.31 \mathrm{a}$ \\
\hline 15 & $44.95 \pm 4.07 \mathrm{bc}$ & $52.03 \pm 2.02 b$ & $55.74 \pm 4.16 \mathrm{c}$ & $67.96 \pm 25.69 b$ \\
\hline \multirow[t]{2}{*}{20} & $52.39 \pm 1.68 \mathrm{c}$ & $61.92 \pm 6.95 \mathrm{c}$ & $63.44 \pm 0.67 \mathrm{~d}$ & $70.64 \pm 25.07 b$ \\
\hline & $F=9.29 * *$ & $F=23.87 * *$ & $F=81.64 * *$ & $F=0.921 @$ \\
\hline
\end{tabular}

* Each value represents mean \pm SD of three independent experiments; ${ }^{@}$ Not significant

** The values represent the means $( \pm \mathrm{SD})$ of three independent experiments. Means within a column followed by the same letter are not significantly different from each other at $p=0.05$ according to Duncan's multiple range test (DMRT) 
Table 3 FRAP activity of the three compounds

\begin{tabular}{|c|c|c|c|c|}
\hline \multicolumn{5}{|l|}{ Ascorbic acid equivalents ( $\mu$ moles/ml) } \\
\hline \multirow[t]{2}{*}{ Concentration of the compounds $(\mu \mathrm{g} / \mathrm{ml})$} & \multicolumn{4}{|c|}{ Name of the compounds } \\
\hline & BC 01_C1* & BC 01_C2* & BC 01_C3* & Ascorbic acid* \\
\hline 5 & $42.00 \pm 5.00 \mathrm{a}$ & $38.56 \pm 1.42 \mathrm{a}$ & $41.50 \pm 1.32 \mathrm{a}$ & $25.33 \pm 2.51 \mathrm{a}$ \\
\hline 10 & $46.33 \pm 4.04 \mathrm{ab}$ & $43.30 \pm 1.60 \mathrm{~b}$ & $47.83 \pm 1.19 b$ & $42.66 \pm 2.51 b$ \\
\hline 15 & $52.66 \pm 2.08 \mathrm{bc}$ & $48.16 \pm 3.68 \mathrm{c}$ & $55.83 \pm 2.32 \mathrm{c}$ & $53.33 \pm 3.21 \mathrm{c}$ \\
\hline \multirow[t]{2}{*}{20} & $60.00 \pm 4.00 \mathrm{c}$ & $56.66 \pm 2.51 \mathrm{~d}$ & $59.53 \pm 3.00 \mathrm{c}$ & $69.33 \pm 4.50 \mathrm{~d}$ \\
\hline & $F=11.95^{* *}$ & $F=29.19^{* *}$ & $F=44.62 * *$ & $F=94.64^{* *}$ \\
\hline
\end{tabular}

* Each value represents mean $\pm \mathrm{SD}$ of three independent experiments

** The values represent the means $( \pm \mathrm{SD})$ of three independent experiments. Means within a column followed by the same letter are not significantly different from each other at $p=0.05$ according to Duncan's multiple range test (DMRT)

Table 4 Total antioxidant capacity of the three compounds

\begin{tabular}{|c|c|c|c|c|}
\hline \multicolumn{5}{|l|}{ Ascorbic acid equivalents $(\mu \mathrm{moles} / \mathrm{ml})$} \\
\hline \multirow[t]{2}{*}{ Concentration of the compounds $(\mu \mathrm{g} / \mathrm{ml})$} & \multicolumn{4}{|c|}{ Name of the compounds } \\
\hline & BC 01_C1* & BC 01_C2* & BC 01_C3* & Ascorbic acid* \\
\hline 5 & $15.33 \pm 2.08 \mathrm{a}$ & $12.90 \pm 0.17 \mathrm{a}$ & $13.66 \pm 9.23 \mathrm{a}$ & $19.33 \pm 5.50 \mathrm{a}$ \\
\hline 10 & $29.66 \pm 11.50 \mathrm{a}$ & $18.73 \pm 4.81 \mathrm{a}$ & $30.00 \pm 19.92 \mathrm{ab}$ & $33.00 \pm 10.81 b$ \\
\hline 15 & $44.00 \pm 19.69 \mathrm{ab}$ & $49.36 \pm 30.54 \mathrm{ab}$ & $51.16 \pm 32.68 \mathrm{ab}$ & $56.33 \pm 12.66 \mathrm{c}$ \\
\hline \multirow[t]{2}{*}{20} & $67.00 \pm 29.51 b$ & $67.83 \pm 24.79 b$ & $60.00 \pm 22.98 b$ & $71.33 \pm 17.03 d$ \\
\hline & $F=4.17^{* *}$ & $F=5.13 * *$ & $F=2.52 @$ & $F=10.86^{* *}$ \\
\hline
\end{tabular}

* Each value represents mean $\pm \mathrm{SD}$ of three independent experiments; ${ }^{@}$ Not significant

** The values represent the means $( \pm \mathrm{SD})$ of three independent experiments. Means within a column followed by the same letter are not significantly different from each other at $p=0.05$ according to Duncan's multiple range test (DMRT)

compounds, BC 01_C1 $(60.00 \pm 4.00)$ exhibited higher ferric reducing antioxidant activity followed by BC 01_C3 $(59.53 \pm 3.00)$ and BC 01_C2 $(56.66 \pm 2.51)$, respectively, at $20 \mu \mathrm{g} / \mathrm{ml}$ of concentration. According to the ANOVA analysis there was significant variation of ferric reducing antioxidant power with respect to ascorbic acid equivalents among the three compounds BC 01_C1, BC 01_C2 and BC 01_C3. Duncan's grouping analysis showed that there was a significant variation within each group at various concentrations. Among these, BC 01_C2 showed significant variation of all the four concentrations whereas BC 01_C1 showed at concentrations, of between $5 \mu \mathrm{g} / \mathrm{ml}, 15 \mu \mathrm{g} / \mathrm{ml}$, and $20 \mu \mathrm{g} / \mathrm{ml}$ was also a significance variance between 10 and $20 \mu \mathrm{g} / \mathrm{ml}$. Compound BC 01_C3 exhibited significance variance between 5,10 and $15 \mu \mathrm{g} /$ $\mathrm{ml}$, but not 15 and $20 \mu \mathrm{g} / \mathrm{ml}$. The results are tabulated in Table 3.

The total antioxidant capacity activity was expressed as $\mu \mathrm{m} / \mathrm{ml}$ of ascorbic acid equivalents. Increase of the absorbance indicated the increase of the total antioxidant capacity. Among the three compounds the TAC was found to be highest for BC 01_C2 $(67.83 \pm 24.79)$ followed by
BC 01_C1 $(67.00 \pm 29.51)$, BC 01_C3 $(60.00 \pm 22.98)$, respectively, at a concentration of $20 \mu \mathrm{g} / \mathrm{ml}$. The compounds possess worthy total antioxidant capacity activity when compared with the standard ascorbic acid. According to the ANOVA analysis, there was a significant variation of total antioxidant capacity observed for the compounds BC 01_C1 and BC 01_C2, but in case of BC 01_C3, there was no significant variation. Duncan's grouping analysis showed that there was a significant variation for compounds BC 01_C1 and BC 01_C2 at concentrations of among 5,15 and $20 \mu \mathrm{g} / \mathrm{ml}$ and also a significant variation between 10 and $20 \mu \mathrm{g} / \mathrm{ml}$. For compound BC 01_C3 exhibited significant variation between 5 and $20 \mu \mathrm{g} / \mathrm{ml}$ but not between $10 \mu \mathrm{g} / \mathrm{ml}, 15 \mu \mathrm{g} / \mathrm{ml}$, and $20 \mu \mathrm{g} / \mathrm{ml}$. The results are tabulated in Table 4.

Crude extract of BC 01 showed significant DPPH radical scavenging activity $68.91 \pm 21.00$, and FRAP activity $78.00 \pm 15.10$ ascorbic acid equivalents and total antioxidant activity $93.33 \pm 2.52$ ascorbic acid equivalents at a concentration of $20 \mu \mathrm{g} / \mathrm{ml}$ (Rao and Rao 2013).

It is essential to use more than one method to evaluate the antioxidant activity of isolated compounds. The 
mechanism involved in antioxidant activity is the ability to donate a hydrogen atom to a radical, and the propensity for donating hydrogen is a critical factor in free radical scavenging (Bondet et al. 1997). The DPPH free radical scavenging assay has been widely used to evaluate antioxidant capacities. Antioxidants react with DPPH, reducing a number of DPPH molecules equal to the number of available hydroxyl groups (Matthaus 2002). The degree of discoloration indicates that the samples to scavenge free radical due to its ability to donate hydrogen proton this shows that when the concentration of the compound increased the free radical scavenging activity also increases. All the three compounds possess worthy activity but the compound BC 01_C3 exhibited potent DPPH free radical scavenging activity and TAC when compared with other two compounds. The FRAP assay is commonly used in routine analysis for evaluation of antioxidant capacity. In the present study the compound BC 01_C1 exhibited potent ascorbic activity equivalents when compared with other two compounds. The reducing capacity of a compound might serve as a significant indicator of its potential antioxidant capacity. FRAP assay measures the reducing capability of tested sample by increasing sample absorbance based on the ferrous ions released (Prior et al. 2005). Similar type of study was conducted by Saurav and Kannabiran (2012) and reported a compound 5-(2,4dimethylbenzyl) pyrrolidin-2-one isolated from marine Streptomyces VITSVK5 exhibited potent the DPPH radical scavenging and phosphomolybdenum reduction activities (44.13 and $50.10 \%$ at $5 \mu \mathrm{g} / \mathrm{ml}$, respectively). In another study, Kumaqai et al. (1993) reported a compound PC-766 B isolated from Nocardia brasiliensis exhibited dose-dependent antioxidant activity. In addition, the compounds 2-allyoxyphenol (Arumugam et al. 2010) and streptopyyrolidine isolated from Streptomyces were reported to possess antioxidant activity (Shin et al. 2008). Likewise, Kim et al. (2008) isolated a compound Protocatechualdehyde from Streptomyces lincolnensis M-20 that exhibited potent antioxidant activity, and also meromonoterpene compounds like Cymopo and avrainvilleol isolated from marine sponges exhibited potent antioxidant activity (Takamatsu et al. 2003).

\section{In vitro anti-inflammatory activity by HRBC membrane stabilization method}

The purified compounds were examined for their in vitro anti-inflammatory activity by HRBC membrane stabilization method. Stabilization of the RBCs membrane was studied to establish the mechanism of anti-inflammatory action of three compounds extracted from Streptomyces coelicoflavus BC 01 . The anti-inflammatory activity was expressed as $\%$ of inhibition. Among the three compounds, the \% of inhibition was found to be highest for BC 01_C3 $(82.86 \pm 12.47)$ followed by BC 01_C1 (73.89 \pm 12.50$)$ and BC 01_C2 (71.26 \pm 2.53$)$, respectively, at their highest concentration, $20 \mu \mathrm{g} / \mathrm{ml}$. All the three compounds possess potent anti-inflammatory activity when compared with the standard Diclofenac sodium. According to the ANOVA analysis there was a significant variation of antiinflammatory activity that was observed for the compounds BC 01_C1 and BC 01_C2, but in case of BC 01_C3 no significant variance was observed. In Duncan's grouping analysis there was a significant variation observed for BC 01_C1 and BC 01_C2 at concentrations of among 50, 100 and $200 \mu \mathrm{g} / \mathrm{ml}$ but no significant difference was observed in between 100 and $200 \mu \mathrm{g} / \mathrm{ml}$. In case of compound BC 01_C3 no significant variation was observed for all the concentrations and the results are tabulated in Table 5.

The compounds effective in inhibiting the hypotonic solution induced haemolysis at different concentrations. The three compounds may possibly inhibit the release of lysosomal content of neutrophils at the site of inflammation. These neutrophil lysosomal constituents include bactericidal enzymes and proteases, which upon extracellular release cause further tissue inflammation and damage (Chou 1997). The haemolytic effect of hypotonic solution is related to excessive accumulation of fluid within the cell

Table 5 Anti-inflammatory activity of the three isolated compounds

\begin{tabular}{lllll}
\hline$\%$ of inhibition & \multicolumn{3}{l}{} \\
\hline Concentration of the compounds $(\mu \mathrm{g} / \mathrm{ml})$ & \multicolumn{4}{l}{ Name of the compounds } \\
\cline { 2 - 6 } & BC 01_C1* & BC 01_C2* & BC 01_C3* & Diclofenac sodium* \\
\hline 50 & $36.79 \pm 9.74 \mathrm{a}$ & $56.79 \pm 1.13 \mathrm{a}$ & $50.23 \pm 20.48 \mathrm{a}$ & $62.96 \pm 7.01 \mathrm{a}$ \\
100 & $57.51 \pm 2.93 \mathrm{~b}$ & $67.65 \pm 4.67 \mathrm{~b}$ & $67.51 \pm 19.94 \mathrm{a}$ & $76.17 \pm 4.73 \mathrm{~b}$ \\
200 & $73.89 \pm 12.50 \mathrm{~b}$ & $71.26 \pm 2.53 \mathrm{~b}$ & $82.86 \pm 12.47 \mathrm{a}$ & $84.35 \pm 3.66 \mathrm{~b}$ \\
& $F=11.96^{* *}$ & $F=17.23^{* *}$ & $F=2.46 @$ & $F=12.01^{* *}$
\end{tabular}

* Each value represents Mean \pm SD of three independent experiments; ${ }^{\circledR}$ Not signficant

** The values represent the means $( \pm \mathrm{SD})$ of three independent experiments. Means within a column followed by the same letter are not significantly different from each other at $p=0.05$ according to Duncan's multiple range test (DMRT) 
resulting in the rupturing of its membrane. Such injury to $\mathrm{RBC}$ membrane will further render the cell more susceptible to secondary damage through free radical-induced lipid peroxidation (Ferrali et al. 1992). Compounds with membrane stabilizing properties are well known for their ability to interfere with the early phase of inflammatory reactions, namely the prevention of the release of phospholipases that trigger the formation of inflammatory mediators (Aitadafoun et al. 1996). In the present study the three compounds isolated from $S$. coelicoflavus BC 01 showed potent anti-inflammatory activity. Earlier studies also revealed that the compounds 5,7,4'-trimethoxy-4phenylcoumarin and 5,7-dimethoxy-4-phenylcoumarin produced from Streptomyces aureofaciens CMUAc130 possess in vitro anti-inflammatory activity (Taechowisan et al. 2007). A polyether compound, dianemycin, isolated from Streptomyces sp. MT 2705-4: KCTC 8651P, showed a potent anti-inflammatory activity (Lee et al. 1997), and also five new anti-inflammatory activity compounds, Phaeochromycins A-E, were isolated from the Streptomyces phaeochromogenes LL-P018 (Graziani et al. 2005). For findings the anti-inflammatory compounds from Streptomyces, a compound lansai C extracted from Streptomyces sp. SUC1exhibits potent in vitro anti-inflammatory activity (Taechowisan et al. 2007). Three peptides, Salinamide C, E and D isolated from marine Streptomyces sp. CNB-091 act as anti-inflammatory peptides. These metabolites are useful as antibiotic and anti-inflammatory agents (Moore et al. 1999). Cyclomarin A is a new cyclic heptapeptides antibiotic isolated from Streptomyces sp. It exhibited significant anti-inflammatory activity in both in vivo and in vitro assays (Renner et al. 1999). Consequently, the compound isolated from Streptomyces coelicoflavusBC 01might be a natural source of membrane stabilizer and capable of providing an alternative remedy for the management and source of membrane stabilizer.

In our search for antibiotic producers from mangrove soil the isolate Streptomyces coelicoflavus BC 01 was capable of producing antibiotics, the antibiotics generated by Streptomyces coelicoflavus BC 01 is a primary bioactive constituent isolated from the culture filtrate, after conducting the separation and purification procedures its structure was determined by using spectroscopic techniques. Neither the proposed molecular structure of the isolated three antibiotic compounds, nor its molecular weight, resembles any of the antibiotics generated by any of the strains of Streptomyces species. Finally, by conducting a search using chemspider as well as a survey of the available literature, the structure of the antibiotic generated by this local strain in the present investigation proved not to be identical with any other reported antibiotics. The antibiotic compounds evidenced an in vitro antimicrobial activity against gram-positive and gram- negative bacteria, as well as fungi and also exhibit in vitro antioxidant and anti-inflammatory activity.

Acknowledgements The author (K.V. Raghava Rao) gratefully acknowledges the University Grants Commission (UGC), New Delhi, India, for providing financial assistance under Non-SAP scheme to study this work and also Prof. Y.L.N. Murthy, Department of Organic Chemistry, Andhra University, for his assistance in structural elucidation.

\section{Compliance with ethical standards}

Conflict of interest All authors have none to declare. This research work did not involve any animals or humans.

Open Access This article is distributed under the terms of the Creative Commons Attribution 4.0 International License (http:// creativecommons.org/licenses/by/4.0/), which permits unrestricted use, distribution, and reproduction in any medium, provided you give appropriate credit to the original author(s) and the source, provide a link to the Creative Commons license, and indicate if changes were made.

\section{References}

Aitadafoun M, Mounieri C, Heyman SF, Binistic C, Bon C, Godhold J (1996) 4-Alkoxybenzamides as new potent phosholipase A2 inhibitors. Biochem Pharmacol 51:737-742

Arumugam M, Mitra A, Jaisankar P, Dasgupta S, Sen T, Gachhui R, Kumar Mukhopadhyay U, Mukherjee J (2010) Isolation of an unusual metabolite 2-allyloxyphenol from a marine actinobacterium, its biological activities and applications. Appl Microbiol Biotechnol 86:109-117

Baltz RH (1998) Genetic manipulation of antibiotic producing Streptomyces. Trends Microbiol 6:76-83

Benzie I, Strain J (1996) The ferric reducing ability of plasma (FRAP) as a measure of antioxidant power: the FRAP assay. Anal Biochem 239:70-76

Berdy J (2005) Bioactive microbial metabolites. J Antibiot 58:1-26

Bondet V, Williams WB, Berset C (1997) Kinetics and mechanisms of antioxidant activity using the DPPH free radical method. Lebensm-Wiss u-Technol 30:609-615

Chou CT (1997) The anti-inflammatory effect of Tripterygium wilfordii Hook $\mathrm{F}$ on adjuvant induced paw edema in rats and inflammatory mediators release. Phytother Res 11:152-154

Cundlife E (1989) How antibiotic producing organisms avoid suicide. Annu Rev Microbiol 43:207-233

Ferrali M, Signorni C, Ciccoli L, Comporti M (1992) Iron release and membrane damage in erythrocytes exposed to oxidizing agents phenylhydrazine, divicine and isouramil. Biochem J 285:295-301

Fguira LFB, Fotso S, Mehdi RBA, Mellouli L, Laatsch H (2005) Purification and structure elucidation of antifungal and antibacterial activities of newly isolated Streptomyces sp. strain US80. Res Microbiol 156:341-347

Gandhidasan R, Thamaraichelvan A, Baburaj S (1991) Anti-inflammatory action of Lannea coromandelica by HRBC membrane stabilization. Fitoterapia 62:81-83

Graziani EI, Ritacco FV, Bernan VS, Telliez J (2005) Phaeochromycins A-E, anti-inflammatory polyketides isolated from the soil actinomycete Streptomyces phaeochromogenes LL-P018. J Nat Prod 68(8):1262-1265

Kim Kyoung-Ja, Kim Mi-Ae, Jung Jee-Hyung (2008) Antitumor and Antioxidant Activity of Protocatechualdehyde Produced from 
Streptomyces lincolnensisM-20. Arch Pharm Res 31(12):1572-1577

Kumaqai K, Fukui A, Tanaka S, Ikemoto M, Moriquchi K, Nabeshima S (1993) PC-766B, a new macrolide antibiotic produced by Nocardiabrasiliensis II. Isolation, physico-chemical properties and structures elucidation. J Antibiot 46:1139-1144

Lechevalier HA (1975) Production of the same antibiotics by members of different genera of microorganisms. Adv Appl Microbiol 19:25-45

Lee SJ, Kim HP, Park BK, Ahn SC, Lee HS, Ahn JS (1997) Topical anti-inflammatory activity of dianemycin isolated from Streptomyces sp. MT 2705-4. Arch Pharm Res 20(4):372-374

Maguelez EM, Hardisson C, Manzanal MB (2000) Streptomycetes: a new model to study cell death. Int Microbiol 3:153-158

Martín JF, Casqueiro J, Liras P (2005) Secretion systems for secondary metabolites: how producer cells send out messages of intercellular communication. Curr Opin Microbiol 8:282-293

Matthaus B (2002) Antioxidant activity of extracts obtained from residues of different oilseeds. J Agric Food Chem 50:3444-3452

Mehdi RBA, Sioud S, Fguira LFB, Bejar S, Mellouli L (2006) Purification and structure determination of four bioactive molecules from a newly isolated Streptomyces sp. TN97 strain. Process Biochem 41:1506-1513

Mellouli L, Mehdi RBA, Sioud S, Salem M, Bejar S (2003) Isolation, purification and partial characterization of antibacterial activities produced by a newly isolated Streptomyces sp. US24 strain. Res Microbiol 154:345-352

Moore BS, Trischman JA, Seng D, Kho D, Jensen PR, Fenicle W (1999) Salinamides, anti-inflammatory depsipeptides from a marine streptomycete. J Org Chem 61:1445-1450

Newman DJ, Cragg GM (2007) Natural products as sources of new drugs over the last 25 years. J Nat Prod 70:461-477

Parasuraman S, Kumar EP, Kumar A, Emerson SF (2010) Free radical scavenging property and diuretic effect of triglize, a polyherbal formulation in experimental models. J Pharmacol Pharmacother 1:38-41

Prieto P, Pineda M, Aguilar M (1999) Spectrophotometric quantitation of antioxidant capacity through the formation of a phosphomolybdenum complex: specific application to the determination of vitamin E. Anal Biochem 269:337-341

Prior RL, Wu XL, Schaich K (2005) Standardized method for the determination of antioxidant capacity and phenolics in foods and dietary supplements. J Agric Food Chem 53:4290-4302
Raghava Rao KV, Ravikiran Ch, Bhaskara Rao D, Madhavi Y, Koteswara Rao P, Raghava Rao T (2012) Antagonistic activities of actinobacteria from mangrove sediment. Int J Pharm Pharm Sci 4(1):364-367

Rao KVR, Rao TR (2013) Molecular characterization and its antioxidant activity of a newly isolated Streptomyces coelicoflavus BC 01 from mangrove soil. J Young Pharm 5:121-126

Renner MK, Shen YC, Cheng XC, Jensen PR, Frankmoelle W, Kauffman CA, Fenical W, Lobkovsky E, Clardy J (1999) Cyclomarins A-C, New anti-inflammatory cyclic peptides produced by a marine bacterium (Streptomyces sp.). J Am Chem Soc 121:11273-11276

Saurav K, Kannabiran K (2012) Cytotoxicity and antioxidant activity of 5-(2,4-dimethylbenzyl)pyrrolidin-2-one extracted from marine Streptomyces VITSVK5 spp. Saudi J Biol Sci 19:81-86

Shin HJ, Kim TS, Lee HS, Park JY, Choi I-K, Kwon HJ (2008) Streptopyrrolidine, an angiogenesis inhibitor from a marinederived Streptomyces spp. KORDI-3973. Phytochemistry 69:2363-2366

Smaouia S, Melloulia L, Lebrihib A, Coppelc Y, Fguiraa LFB, Mathieu F (2011) Purification and structure elucidation of three naturally bioactive molecules from the new terrestrial Streptomyces sp. TN17 strain. Nat Prod Res 25:806-814

Taechowisan T, Tuntiwachwuttikul P, Lu C, Shen Y, Lumyong S, Taylor WC (2007) Anti-inflammatory activity of 4-Arylcoumarins from Endophytic Streptomyces aureofaciens CMUAc130 in Murine Macrophage RAW 264.7 Cells. Immunol Invest 36(2):203-211

Takamatsu S, Hodges TW, Rajbhandari I, Gerwick WH, Hamann MT, Nagle DG (2003) Marine natural products as novel antioxidant prototypes. J Nat Prod 66:605-608

Tanaka YT, Mura SO (1993) Agro active compounds of microbial origin. Annu Rev Microbiol 47:57-87

Wiegand I, Hilpert K, Hancock RE (2008) Agar and Broth dilution methods to determine the minimal inhibitory concentration (MIC) of antimicrobial substances. Nat Protoc 3(2):163-175

Xu DB, Ye WW, Han Y, Deng ZX, Hong K (2014) Natural products from mangrove actinomycetes. Mar Drugs 12(5):2590-2613

Zaitlin B, Watson SB (2006) Actinomycetes in relation to taste and odour in drinking water: myths, tenets and truths. Water Res 40(9):1741-1753 